\title{
Two Asian Empresses and Their Influence on the History and Religion in Tang China and Nara Japan (VII-VIII cc.)
}

\author{
Elena Lepekhova ${ }^{1, *}$ \\ ${ }^{1}$ Institute of Oriental Studies, Russian Academy of Sciences, Moscow, Russia \\ *Correspondence: Senior Research Officer, 107031, Moscow, Rogdestvenka 12. Moscow, Russia. E-mail: \\ lenalepekhova@yandex.ru
}

Received: May 1, 2017

Accepted: June 26, 2017 Online Published: July 12, 2017

doi:10.5430/sass.v4n2p20

URL: https://doi.org/10.5430/sass.v4n2p20

\begin{abstract}
The main issue of this paper is the role of two empresses: Chinese Wu Zhao (624-705) and Japanese Koken (Shotoku, 718-770) in the history and religion in China and Japan. Both female rulers took Buddhist percepts and patronized the Buddhist Sangha in order to legitimate their power. As the female rulers in the mostly patriarchal society, both Wu Zhao and Koken had numerous enemies among the formidable court officials and influential families who opposed their rule. Therefore, they both used various auspicious signs and omens as the calculated political tools to secure their position. In various documents (edicts, manuals etc.) both $\mathrm{Wu}$ Zhao and Koken used the examples, mostly from Buddhism, to show their legitimate status. However, despite of their contribution in the state government and religious system, both empresses Wu Zhao and Koken were reviled as bad rulers by the later Confucian historians who resented their patronage of Buddhism and the fact that they were female rulers.
\end{abstract}

Key words: Wu Zhao, Koken, China, Japan, Buddhist Sangha, confucian historians

\section{Introduction}

The empress $\mathrm{Wu}$ Hou 武后 (Wu Zhao 武晊, Wu Zetian 武則天, February 17, 624-December 16, 705) is considered as one of the most remarkable figures in Chinese history. She was a first woman in Chinese history, who proclaimed herself as huangdi ("the emperor of China") and the founder of Zhao dynasty. During many years, Wu Hou ruled China first, as an empress-consort (huanghou) of the emperor Gaozong (650-683), than, as an empress-dowager of her sons Zhun-tsun and Zhui-tsun, and in 690-704 as the autocratic ruler. Although China did not have a written Salic law, nevertheless there was a prohibition, silently observed through dynasties, that a woman should not become emperor. Given this deeply entrenched cultural attitudes, Wu Zhao clearly could not and did not construct her political authority in a conventional fashion. (Rothschild, 2015: P. 2) Necessarily, she sought alternative sources of legitimacy both within and beyond the confines of the Confucian tradition. She keenly justified her status, firstly, by including in the state doctrine the Buddhist and Taoist ideas and secondly, giving a new interpretation of the traditional ideals of governance. The social and economic basis of her reign were the rational reforms, necessary in the field of economics, taxation, administrative and military culture. The main force of Wu Hou's government were the officials from middle class, to whom the examination system, which during her reign gained the regular and flexible nature, provided real access to the highest posts in the government.

\section{Reforms of Wu Hou}

While her organization of the civil service system was criticized for its laxity of the promotion of officials, meanwhile, Wu Zetian strictly observed and evaluated how the officials perform their duties. The Song Dinasty historian Sima Guang (1019-1086 AD), in his Zizhi Tongjian 資治通鑑 ("Comprehensive Mirror in Aid of Governance"), wrote about it:

"Even though the Empress Dowager excessively used official titles to cause people to submit to her, if she saw that someone was incompetent, she would immediately depose or even execute him. She grasped the powers of punishment and award, controlled the state, and made her own judgments as to policy decisions. She was observant and had good 
judgment, so the talented people of the time also were willing to be used by her." (Zizhi Tongjian, vol. 205 http://www.guoxue.com/shibu/zztj/content/zztj_205.htm)

Most of Wu Zhao reforms were connected with the imperial examination system. The basic theory and practice of this one was to recruit into government service those men who were the best educated, talented, and having the best potential to perform their duties in the bureaucratic government structure of the Chinese empire. The candidates were male only, and their qualification and resulting placements into official positions was on a relatively small scale at the time of Wu's assuming control of government. The official tests included determining the potential official's level of literacy in terms of reading and writing as well as his possession of the specific knowledge considered necessary for a governmental official, such as Confucian socio-ethical philosophy about the relationships within society. Wu Zetian continued to use the imperial examination system to recruit civil servants, and she introduced major changes in regard to the system that she inherited, including increasing the number of candidates, by allowing commoners and gentry, who were previously disqualified by their background. (Paludan, 1998: 97)

The successful candidates who were recruited through the examination system became an elite group within her government. Toward the end of Gaozong's life, Wu began engaging a number of officials who had literary talent, including Yuan Wanqing (元萬頃), Myao Chuke (苗楚客), Zhou Simao (周思茂), and Han Chubin (韓楚賓), to write a number of special works, including the Biographies of Notable Women (列女傳), Guidelines for Imperial Subjects (臣軌), and New Teachings for Official Staff Members (百僚新誡). Collectively, this group of literati became known as the "North Gate Scholars" (北門學士), because they served inside the palace, which was to the north of the imperial government buildings, and Empress $\mathrm{Wu}$ sought advice from them to divert the powers of the chancellors. (Fairbank, John King, 1992: 82) Through a process of eliminating the power of the established aristocracy, whom she regarded as disloyal to her, and establishing a reformed upper class in China loyal to her, Wu Zetian made major social changes which were later evaluated by historians. Many of Wu Zetian's measures were of a popular nature, first of all, to gain support for her authority. She was determined that free, self-sufficient farmers would work most effectively on their own farm land, so she periodically used the juntian, equal-field system to ensure fair land allocations. (IBID) Her various edicts, which helped to satisfy the needs of the lower classes through various acts of relief, widening recruitment of the previously excluded gentry and commoners to the government service, and generous promotions for the lower ranks, contributed much to her popularity in masses. (Paludan, 1998: 100)

\section{Wu Hou's Religious Policy}

Wu Hou used to increase her power by manipulating Buddhist, Daoist, and Confucianist religious cults and philosophical ideas. Mostly, it was connected with the idea of the Mandate of Heaven. Wu began to manipulate the symbolic aspects of religious and imperial power long before she became huangdi. Her participation in Feng and Shan sacrifices at Mount T'ai, in 666 was considered as a unique undertaking. The Feng and Shan were probably state rituals in premodern China, imbued with the most momentous religious and political symbolism. Traditionally held at mount T'ai and a nearby hill in modern Shantung, the rituals represented a confirmation of the rules receipt of the Heavenly Mandate. In this rites, the emperor announced to the heaven the success of his rule and expressed thanks for the blessings of Heaven and Earth. By doing so, he showed to the whole known world the legitimacy of his government in a most formal and august manner. (Cheng Jo-shui,1994: 84)

Either in the tenth month of 665, when the imperial party was about to leave the capital Loyang for the mount T'ai, or in the twelfth month, just before the Feng and Shan sacrifices, empress Wu raised the issue of her participation in this rites. In her memorial concerning this matter, she agreed to the arrangements for the Feng, but objected to one major aspect of the proposed Shan rite. According to the regulations, governing the ceremonies, in the Shan sacrifices high officials made the secondary and tertiary offerings. Wu claimed that this arrangement was inappropriate; she should be the one, making the offerings, with assistance of women from official ranks and noble titles (including imperial consorts, female palace officials, female relatives of the emperor, and eminent officials mothers and wives). (IBID, 84) The objects of Shan's sacrifice were the God of Earth and it's associated ancestral deities - Empresses T'ai-mu and Wen-te, the wives of the late emperor Gaozong. The likely reason, why the two empresses were made associated ancestral deities in this rite was that Earth was symbolically the mother of the Chinese emperor, whereas Heaven was his father. In her memorial empress Wu contended, that since the associated deities were female, there was no reason for male ministers accompanying the emperor for offering sacrifices. Moreover, as a housewife in the imperial family, she regretted that she had no opportunity to serve these two empresses, her mother-in-law and grandmother-in-law. The Shan ritual was the ideal situation, in which she could fulfill her duties by offering sacrifices to the spirits of these two empresses. If she were to be allowed to take part in the Shan, Wu 
concluded, it would be a good to demonstrate true moral standards to the empire and later generations. (IBID, 85)

As a result of Empress Wu's request, women played a prominent role in the Shan sacrifice. Empress Wu made the secondary offering and a concubine of the deceased emperor T'ai-tsung made the territory offering, with palace ladies, assisting at the altar. The participation of empress $\mathrm{Wu}$ and other palace women in the 666 Feng and Shan sacrifices was indeed remarkable. As co-ruler of the country, she most likely felt that her appearance in such a hallowed rite would help establish the legitimacy of her status. The 666 Feng and Shan were open public ceremonies; the spectators included not only imperial princes and government officials but also specially skilled and talented commoners and representatives of many foreign countries and tribes. As a T'ang woman, Wu couldn't possibly appear in a grand state ritual alone, surrounded by man; she needed to bring in female assistants. On the other hand, the conspicuous presence of women in the Shan sacrifice no doubt greatly enhanced the general visibility of women in T'ang political life. This was a scenario that a person as intelligent and calculating as empress Wu could week have anticipated. (IBID, 85) The other scholar, Ann Paladin also points out, that Wu Zetian's procession of ladies up Taishan conspicuously linked Wu with the most sacred traditional rites of the Chinese empire. (Paludan, 1998: 99)

Chen Jo-shui also argues, that Wu's rule as the emperor of China was such an unusual and striking development, that she felt the need to exert tremendous effort to legitimize it (Cheng Jo-shui,1994: 84). This aspect of Wu's political life had been a focal point of many studies of her. Wu's most unorthodox legitimation measure was her attempt to justify a female emperorship by using Buddhist ideas. The critical Buddhist text, that Wu's supporters utilized, was the "Great Cloud Sutra" (Ch. "Ta-yün ching", Sn. "Mahamegha sutra"), in which the Buddha prophesied, that a woman would become a chakravartin, an omnipotent king, who was also a Bodhisattva-savior. In Chou state ideology, Wu was mainly identified as this chakravartin, but also as a Maitreya incarnate. (IBID) The reason why Wu resorted to Buddhism to establish her legitimacy as a female ruler, was a fact that in the indigenous Confucian doctrine, women had no place in political life. By including Buddhist doctrines in her political ideology, Wu certainly did try to prove that women had a rightful claim to take part in governing the empire.

Tansen Sen consider that Wu Zeitan's plans to use Buddhism for legitimizing her authority were evident by the late 685. During this year the empress ordered the construction of the tower tyantang (Celestial Hall) to the Buddhist monk Hyaiyi, who was one of her closest counselors, within the Luminous Hall complex at Luoyang. Antonino Forte, who has examined in detail the process of constructing the Celestial Hall, argues that this architectural structure essentially served as a "Maytreyan tower". It is remarkable, that Huaiyi, the chief architect of the hall, was himself a leader of contemporary Maytreyan movement. The principle text used by Huaiyi and the followers of Maytreyan cult was "Puxian pusa shuo zhenming jing" ("The Attestation Sutra spoken by Bodhisattva Samantabhadra"), an apocryphal text complied between 560 and 589. This text contains a prophecy about Maitreya's descent from his current abode in the Tusita Heaven into a "magical city" with a majestic city walls, decorated pavilions, and a magnificent tower. The text professes that only those who were destined for salvation would be admitted into this city (Tansen Sen, 2003: 94).

It seems that the planned construction of the Celestial Hall and the naming of Luoyang as the "Divine Capital" were based on the description of the "magical city" in "Pixan pusa shuo shenmig jing". In fact, in 689, when the Celestial Hall was finally completed, there was placed a lacquer statue of Maitreya two hundred seventy meters high. Less than two years after the Celestial Hall was completed, Wu Zeityan declared herself an emperor and established her own Zhou dynasty. (IBID, p. 94)

During this time another attempt to link the empress to Maitreya was made by the Buddhist clergy. A Buddhist commentary called "Dayun jing Shenhuang shouji yi shu" "Commentary on the Meaning of the Prophecy about Shenhuang [Divine Emperor, i.e. Wu Zeitan]") was presented to the court in 691. Although the "Commentary" purports to explain Dharmaksema's fifth-century translation of the canonical work "Dayun jing" ("Mahamegha sutra"), it incorporates numerous passages from the apocryphal "Pixan pusa shuo shenmig jing" to substantiate Maitreya's arrival in China. (IBID, 94)

At the core of the "Commentary" was a prophecy concerning the reincarnation of Devi Jingguang (Vimalaprabha), one of the Buddha's female disciples, as a chakravartyn ruler. In the prophecy, which is drawn from the canonical text "Dayun jing", the Buddha predicts that Devi Vimalaprabha would be reborn to become a powerful, compassionate and pious Buddhist ruler of the entire Jambudvipa (IBID, 94). The authors of the "Commentary" used this prophecy to argue that Wu Zeitan was in reality the same female chakravartyn professed to rule Jambudvipa. This argument may have been employed specifically to address the fact that no woman in China had previously attained the position of emperor. Additionally, the authors of the "Commentary" cited the passage on the "magic city" in "Pixan pusa shuo shenmig jing" to suggest that Maitreya was predestined to arrive in Luoyang, the capital of 
Wu Zeitan. In fact, when presenting the "Commentary" to the court, one of its authors openly declared that Wu Zeitan was an incarnation of Maitreya on Earth and the ruler of entire Jambudvipa. In short, the "Commentary" and its authors portrayed $\mathrm{Wu}$ Zeitan as both a female incarnation and an incarnated Maytreya, reborn to rule over all the kingdoms in Jambudvipa. (IBID, 97)

Five years after the circulation of the "Commentary", Wu Zeitan formally added the name Maitreya (Cishi) to her title. In the meantime, the attempt to legitimize her new Chou dynasty through other Buddhist prophecies continued. In 693, the Indian monk Bodhiruci produced a text called "Baoyu jing" (Ratnamegha sutra), which contained interpolated passages, predicting the appearance of a female bodhisattva-chakravartyn ruler of Jambudvipa in China. Curiously, however, Wu Zeitan in this text was linked to the Bodhisattva Chandraprabha, and not Maytreya (IBID, 97).

Antonino Forte points out, that Bodhiruci had arrived in China on Wu Zeitan's personal request. He suggests that during this time the political use of Buddhist motives and paraphernalia provided tremendous stimulus to Sino-Indian exchanges during the last two decades of seventh century. In order to portray Wu Zeitan as the legitimate ruler not only in China, but the entire continent of Jambudvīpa, the Chinese Buddhist clergy working on behalf of the empress seems to have sought the help of both Chinese and Indian Buddhist monks (IBID, 98). The evidence for the presence and involvement of Indian monks in Wu Zeitan political propaganda comes from a colophon found on the Dunghuang manuscript of "Ratnamegha sutra". The colophon records the names, functions and titles of people who participated in the translation of the sutra under the supervision of the monk Huaiyi. Of the thirty people listed on the colophon, nine were Indian monks. In connection to Wu Zeitan's employment of Indian nationals, should be mentioned Gautama Luo (Rahula?), an Indian astronomer who held the position of Director of Astronomy (Tai shi ling) between 665 and 698. The fact that an Indian held the highest position in an important state office that was in charge of interpreting heavenly phenomenon on behalf of the Chinese ruler is noteworthy. As Forte has observed, the initial interest in Indian astronomers and their mathematical techniques was connected to $\mathrm{Wu}$ Zeitan's plans to legitimize her authority. The correct calculation of time, especially the period from Buddha's nirvana to the decline of Dharma and the advent of Maitreya, constituted an important component of Chinese Buddhism. Probably, the empress installed Gautama Luo as the Director of Astronomy for the legitimization of her authority, in 665, when she ascended the throne of Tang dynasty. Even the Indian embassy of 692, which reported to have consisted of royalty from various regions of India, may have been part of Wu Zeitan's attempt to legitimize her rule. Although, it is unlikely that Indian kings would leave their kingdom and travel to China, the episode is nonetheless indicative of Wu Zeitan's use of Indian symbolic to legitimize her position as the chakravartin ruler of entire Jambudvipa, including China. (IBID, p. 98)

Shortly after Wu Zetian took the throne, she officially raised the status of Buddhism, by building temples named Dayun Temple (大雲寺) in each prefecture belonging to the capital regions of the two capitals Luoyang and Chang' an. In 673 she collected funds and made huge donations for the building of the statue of Buddha Maytreya in Lunmen caves. (Zizhi Tongjian, vol. 207 http://www.guoxue.com/shibu/zztj/content/zztj_207.htm)

As Tansen Sen argues, Wu Zeitan's reign was one of the most propitious periods for the Buddhist community in China. (Tansen Sen, 2003: p. 98)

\section{Empress Kōken}

In modern scholarship Wu Zetian is frequently compared with another Asian Empress, who lived almost 50 years later. This is a Japanese Empress Kōken 孝謙 (Abe-no Naishinno, 阿倍内親王, Shōtoku 稱德) (749-783), who, becoming a Buddhist nun, continued to rule the state.

The first difference between Kōken and Wu Hou was in their origin. While Wu was born in a merchant's family and, therefore, lately criticized by her enemies as "a person of a vile background", Kōken (or Princess Abe) was a princess of blood, the only daughter and heiress of emperor Shōmu. In the chronicles of that period "Shōku Nihongi" she was called the "Crown Princess" (taishi 太子) (Shōku Nihongi, 1973: 158). In that fact the other difference occurred that Kōken received the abdication of Shōmu and was enthroned also by her father. It means that her enthronement (in comparison with $\mathrm{Wu}$ Zeitan) was considered as legal, during the first years of her reigning.

Yet, the empress Kōken, along with $\mathrm{Wu} \mathrm{Hou}$, also tried to increase her power by manipulating Buddhist, Daoist, and Confucian religious cults and philosophical ideas. First of all, she (probably under the influence of her fatheremperor Shōmu) openly patronized the Buddhist sangha. While ascending the throne, she made rich donations by land property to Buddhist temples, and granted the court ranks to the representatives of local Hayato tribes of Osumi and 
Satsuma. Most officials of the lower ranks also received the promotion. During her trip through the country in autumn 749 , in Ishikawa she "forgave the grain taxes from the farmers in these districts" and in Kawachi region the empress "bestowed the gifts to the monks, nuns and male and female shami 僧尼及沙弥沙弥尼 residing in the 66 temples and other Buddhist residences". (IBID, 275) In the decree of 764 she justified her own reenthronement in the following manner, quoting from the Buddhist sutras (apparently, from the "Sutra of golden light" (Sk. "Suwarnaprabhasa sutra", Jp. “Konkomyōkyō” 金光明經):

"And so We took vows and wore the sacred Buddhist robe, but it is impossible for Us not to rule the state affairs of [our] celestial country. And the Buddha in the Sutra thus have told: "The Lord of the Kingdom during his reign must take the Bodhisattva precepts (kokuō kokui ni zaji wo bosatsu sunawachi jōkai ukete 國王王位坐時菩薩淨戒受).” And, at least, We left the house (became a nun), but now [there] is no obstacles for Us to make the state affairs (seigyo ni ani sawari mono fuzai 政行豈障物不在).”(IBID, pp. 288-289)

It should be noted, that in the other decree from 765 on the celebration of the Shinto ceremony of the first harvest Oonie - no matsuri 大䞇の祭り, Kōken openly proclaims her Buddhist policy:

"Therefore, first of all, We want to serve the Three Treasures (sanbō 三宝), then to honor the gods of Heaven and Earth (kami 神), then to take care about our officials, princes, nobles, the officials of one hundred departments and all the people of the Celestial Empire. So We suppose to rule our Celestial Empire." (IBID, pp. 295) In her other decrees in future, the words "The Law of the Buddha" (buppo 仏法) and "The Three Treasures" (Buddha, Dharma and Sangha) (sanbō 三宝) would always come first.

The Buddhist policy of Empress Kōken largely was determined by the difficulties of her reign. Just two years after ascending the throne, she was removed from power by the coalition that united retired Empress Kōmyō and Great Minister Fujiwara Nakamaro. Kōken was forced to abdicate in favor of the Crown Prince Ooi (733-765) (future Emperor Jūnin 淳仁), but due to the support of the monk Dōkyō 道鏡, she was able to regain power. During the joint reign of Dōkyō and Kōken, several measures were taken to strengthen and control the Buddhist Church. The Buddhist hermits were prohibited to build Buddhist temples in the mountains and forests without official permission. During this time was strengthened the state control over the expenditure of funds, allocated for the provincial Buddhist monasteries. At the same time, the government allocated significant sums and land donations to the Buddhist temples. (Abe, 1999: 21-22)

It is clear, that there are some common features in the political activity of empresses Wu Hou and Kōken. They both patronized the Buddhist church by making land donations and granting privileges to the Buddhist monks and nuns and had the Buddhist monks (Huaiyi and Dōkyō) in their government. During the first years of their reign, both Wu Hou and Kōken tried to increase the role of lower officials by promoting to them higher ranks. Yet while empress Wu relate to the bureaucracy as a means in struggle with the powerful aristocratic clans, Kōken, in this instance, preferred to use the support of Bugghist sangha. Their regiment is also marked with various conspiracies, organized by the court aristocracy and severe repressions from the authorities, even against the members of the emperor's clan. Both Wu Hou and Kōken politically precarious situation made them receptive to various auspicious omens as calculated political tools to secure their position and solidify their power. Wu Hou's reign eras (nian hao) are the most exemplary of this use of symbolism. The changing of the calendar's system during the reign of Kōken had the similar reasons. According to the chronicles "Shōku Nihongi", the news about various auspicious omens were the reasons to change the era names (from Tenpyō Shōhō to Tenpyō Hoji) and, therefore, to grant the officials, free commoners from taxes and to make donations to the Buddhist temples.

\section{Conclusion}

Yet, there are various opinions between the scholars about the historic meaning of these two Asian empresses reigning. About $\mathrm{Wu}$ Hou the traditional Chinese historical view generally was mixed - admiring her for her abilities in governing the state, but vilifying her for her actions in seizing imperial power. In a predominantly patriarchal and patrilineal society, in which the Confucian prescription sequestered women almost exclusively to the inner, domestic sphere, Wu Zhao's political involvement was judged harshly; she was routinely cast as a lewd and extravagant counterpoint to virtuous, austere male rulers, including her first husband Taizong (Rothschild, 2015: 3). Even the modern Chinese and non-Chinese scholars evaluate her biography contradictorily, but mostly they recognize that the results of her government, in general, were positive: "Government was sound, no rebellions occurred, abuses in the army and administration were stamped out and Korea was annexed, an achievement no previous Chinese had ever managed." (Cotterell \& Cotterell, 1975: 144) 
The evaluations of Kōken in the Japanese historiography seems to look rather skeptical. As Abe Ruichi consider, the government of Empress Shōtoku paralyzed the court bureaucracy and seriously disrupted ritsuryō, the official legal procedures of the state. By issuing haphazardly laws aimed only at elevating the power of the ecclesiastic establishment - for example, by destroying the economic foundations of the aristocratic clans of lay ministers, granting greater endowments to monastic institutions, relaxing the restrictions on ordination, and boosting the power of the clergy - Shōtoku's regime created confusion in state policy. That is, as Abe concludes, Shōtoku's court, as well as the Buddhist clergy that supported it, failed to produce a governing principle that would have replaced the ritsuryo system. (Abe, 1999: 21-22) To restore order in the aftermath of the death of Shōtoku in 770, Emperor Kōnin adopted a policy of rebuilding the ritsuryo system that took the form, on one hand, of revitalizing the State College (Daigaku), the official Confucian educational institution that trained elite students from the aristocracy for higher government service, and on the other, of imposing strict ritsuryo measures aimed at containing the influence of the Japanese Buddhist establishment. (IBID)

However, whatever complex and controversial were the struggle for power and political activity of these two Asian empresses, they both sought to rule the country autocratically. In traditional Chinese and Japanese society this privilege was assessable only for the male emperors, therefore in Confucian historical tradition both Wu Zetian and Kōken were denounced as bad rulers. On my opinion, the historical significance of Wu Hou consists in that fact, that she understood well the importance of bureaucracy in the process of state government, and due to her reforms, in many ways, the prosperity and influence of Tang empire were provided. The role of Kōken's policy still underestimated, because she was the first female sovereign, who tried to institute the religious bureaucracy as governmental apparat, but this attempt was counteracted by aristocratic clans. Actually, the historical meaning of these two Asian empresses consists in, that they both created a new practice of government, when, in spite of the gender or the origin, the ruler could legitimize his (or her) status by religious and philosophical justifications from various (Buddhist, Confucian and Taoist) traditions.

\section{References}

Abe Ryoichi. (1999). The weaving of mantra. Kukai and the construction of Esoteric Buddhist discours. New York: Columbia University Press.

Cheng Jo-shui. (1994). Empress Wu and Proto-Feminist Sentiments in Tang China. In Frederick R. Brandauer \& Chun Chieh Huang (ed.), Imperial Rulership \& Cultural Change in Traditional China. USA: University of Washington Press.

Cotterell, Yong Yap \& Arthur Cotterell. (1975). The Early Civilization of China. New York: G.P.Putnam's Sons

Fairbank, John King. (1992). China: A New History. Cambridge, Massachusetts: Belknap Press/Harvard University Press.

Paludan Ann. (1998). Chronicle of the Chinese Emperors: The Reign-by-Reign Record of the Rulers of Imperial China. New York, New York: Thames and Hudson.

Rothschild N. Harry. (2015). Emperor Wu Zhao and her pantheon of Devies, Divinities and Dynastic Mothers. New York: Columbia University Press.

Shōku Nihongi. (1973). ("Continuation of the "Nihon Shōki”) // Kokushi taikei (Studies in national history), ed. by Kuroita Katsumi, Tokyo: Yoshikawa Kobunkan, V. II

Tansen Sen. (2003). Buddhism, Diplomacy and Trade. The Realignment of Sino-Indian Relations. Honolulu: Association for Asian Studies \& Hawai'i University Press.

Zizhi Tongjian, vol. 205, 207

http://www.guoxue.com/shibu/zztj/content/zztj_205.htm

http://www.guoxue.com/shibu/zztj/content/zztj_207.htm 